\title{
Cikkismertetés: Az iskolai végzettség és halálozás kapcsolata három kelet-európai országban
}

\author{
Article review: Relationship between educational attainment and \\ mortality in three Eastern European countries
}

Ismertető: $\quad$ Devosa Iván $\varangle$

Neumann János Egyetem, Pedagógusképző Kar, Egészségtudományi és

Egészségfejlesztési Kutatócsoport, Kecskemét

Ismertetett cikk: Doniec, K., Stefler, D., Murphy, M., Gugushvili, A., McKee, M., Marmot, M., Bobak, M., King, L. (2019). Education and mortality in three Eastern European populations: findings from the PrivMort retrospective cohort study. European Journal of Public Health, 29(3), 549-554. doi: 10.1093/eurpub/cky254

Beküldve: $\quad$ 2020. 01.24.

doi: $\quad$ 10.24365/ef.v61i2.559

Kulcsszavak: oktatás; halálozás; Kelet-Európa; Magyarország

Keywords: education; mortality; Eastern-Europe; Hungary

\section{HÁTTÉR}

A tanulmány célja kettős: megvizsgálni a politikai és gazdasági változások lehetséges hatásait a különböző iskolai végzettségű férfiak és nők halálozási egyenlőtlenségére három kelet-európai országban, illetve bemutatni a dohányzás és az alkoholfogyasztás szerepének változását az iskolázottságbeli különbségek okozta halálozási egyenlőtlenségekben. A tanulmány az 1982 és 2013 közötti időszakra terjed ki.

\section{MÓDSZER}

Az adatokat véletlenszerűen kiválasztott városi lakosoktól gyűjtötték. Az összes válaszadó korábban született, mint 1972, és legalább egyik családtagjuk ugyanazon településen élt már az 1990-es években is. Az országspecifikus válaszadási arányok 48, 39, illetve 85\% voltak Oroszországban, Fehéroroszországban és Magyarországon: a válaszadási arányokban tapasztalható nagy eltérésekért nagyrészt a minták méretének különbségei a felelősek. A résztvevők információkat szolgáltattak társadalmi-gazdasági körülményeikről, foglalkoztatási előzményeikről, alkoholfogyasztási és dohányzási szokásaikról. A legmagasabb iskolai végzettséget az alábbiak szerint osztályozták: alapfokú vagy az alatti (befejezetlen) iskolai végzettség; középfokú iskolai végzettség; felsőfokú iskolai végzettség.

\section{EREDMÉNYEK}

$A z$ 1. és 2. táblázat mutatja a különböző végzettségűek halálozási esélyhányadosait időszakonként, országonként és nemenként, a felsőfokú végzettséget használva referenciakategóriaként. Az elvárásoknak megfelelően a halálozási arány szignifikán- 
san magasabb volt az alacsonyabb iskolai végzettségú csoportokban a legtöbb időszakban és alcsoportban. Az esélyhányadosok a felsőfokú végzettséghez viszonyítva (referenciakategória) mind a középfokú, mind az alacsonyabb, mint a középfokú végzettség kategóriáiban az idő múlásával növekedtek. Habár ezek a trendek nagyjából hasonlóak voltak minden országban, néhány figyelemre méltó különbséget felfedeztek a kutatók.
Például nem találtak egyértelmű gradienst a halálozási adatok terén a különböző képzettségi csoportok között Oroszországban és Fehéroroszországban 1982-89 és 1990-97 között. Ellentétben a többi ország adataival az esélyhányadosok viszonylag stabilak maradtak a magyar férfiak körében a vizsgálat teljes ideje alatt.

\section{TANULSÁGOK A HAZAI SZAKEMBEREK SZÁMÁRA}

A három kelet-európai országban végzett nagymintás, retrospektív, 32 éves időszakra kiterjedő kohorsz tanulmány adatai felhasználásával a kutatók kimutatták, hogy az 1990-es évek elejének társadalmi-politikai változásait követően az iskolázottságbeli különbségek okozta halálozási egyenlőtlenségek tovább nőttek Oroszországban, Fehéroroszországban és Magyarországon. Az eredmények azt is megmutatják, hogy ehhez az egészségtelen életmód, mint az alkoholfogyasztás és a dohányzás, hozzájárulásának mértéke különösen a férfiak körében szintén növekedett a három vizsgált évtizedben. Ezen adatok is megerősítik annak fontosságát, hogy a magyarországi iskolázottság átlagos szintje emelkedjen, hiszen ennek komoly egészséggazdasági hozadékai vannak mind egyéni, mind össztársadalmi szinten.

\section{KÖSZÖNETNYILVÁNÍTÁS}

Köszönettel tartozom a publikálás támogatásáért, amely az EFOP-3.6.1-16-2016-00006 „A kutatási potenciál fejlesztése és bővítése a Neumann János Egyetemen” pályázat keretében valósult meg. A projekt a Magyar Állam és az Európai Unió támogatásával, az Európai Szociális Alap társfinanszírozásával, a Széchenyi 2020 program keretében valósul meg. 
1. táblázat: A férfiak halálozási esélyhányadosai a különböző iskolai végzettségü csoportok között, időszakonként és országonként

\begin{tabular}{|c|c|c|c|c|c|c|c|c|c|c|c|c|c|c|c|c|c|c|c|c|c|}
\hline \multirow{3}{*}{ Országok } & \multirow{3}{*}{\begin{tabular}{|c|} 
Iskolai \\
végzettség \\
szintje
\end{tabular}} & \multicolumn{4}{|c|}{ 1982-1989 } & \multirow[b]{3}{*}{ AOR\% } & \multicolumn{4}{|c|}{ 1990-1997 } & \multirow[b]{3}{*}{ AOR\% } & \multicolumn{4}{|c|}{ 1998-2005 } & \multicolumn{5}{|c|}{$2006-2013$} & \multirow[b]{3}{*}{ AOR\% } \\
\hline & & \multicolumn{2}{|r|}{$\mathrm{m} 1$} & \multicolumn{2}{|r|}{$\mathrm{m} 2$} & & \multicolumn{2}{|r|}{$\mathrm{m} 1$} & \multicolumn{2}{|r|}{$\mathrm{m} 2$} & & \multicolumn{2}{|r|}{$\mathrm{m} 1$} & \multicolumn{2}{|r|}{$\mathrm{m} 2$} & & \multicolumn{2}{|r|}{$\mathrm{m} 1$} & \multicolumn{2}{|r|}{$\mathrm{m} 2$} & \\
\hline & & OR & $(95 \% \mathrm{Cl})$ & OR & $(95 \% \mathrm{Cl})$ & & $\mathrm{OR}$ & $(95 \% \mathrm{Cl})$ & OR & $(95 \% \mathrm{Cl})$ & & OR & $(95 \% \mathrm{Cl})$ & OR & $(95 \% \mathrm{Cl})$ & AOR\% & OR & $(95 \% \mathrm{Cl})$ & $O R$ & $(95 \% \mathrm{Cl})$ & \\
\hline \multirow{3}{*}{ Oroszország } & felsőfokú & 1,00 & & 1,00 & & & 1,00 & & 1,00 & & & 1,00 & & 1,00 & & & 1,00 & & 1,00 & & \\
\hline & középfokú & 1,39 & $(1,20-1,61)$ & 1,27 & $(1,10-1,47$ & 30,8 & 1,32 & $(1,19-1,47)$ & 1,19 & $(1,06-1,33)$ & 40,6 & 1,43 & $(1,27-1,61)$ & 1,25 & $(1,12-1,40)$ & 41,9 & 1,44 & $(1,26-1,63)$ & 1,21 & $(1,06-1,39)$ & 52,3 \\
\hline & \begin{tabular}{|l|} 
alapfokú \\
vagy alatta
\end{tabular} & 1,36 & $(1,18-1,57)$ & 1,24 & $(1,05-1,46)$ & 33,3 & 1,50 & $(1,33-1,70)$ & 1,32 & $(1,13-1,53)$ & 36,0 & 1,82 & $(1,66-2,00)$ & 1,52 & $(1,35-1,72)$ & $\mid 36,6$ & 1,89 & $(1,57-2,27)$ & 1,48 & $(1,24-1,77)$ & 46,7 \\
\hline \multirow{3}{*}{ Fehéroroszország } & felsófokú & 1,00 & & 1,00 & & & 1,00 & & 1,00 & & & 1,00 & & 1,00 & & & 1,00 & & 1,00 & & \\
\hline & középfokú & 1,32 & $(1,15-1,52)$ & 1,23 & $(1,07-1,40)$ & 28,1 & 1,23 & $(1,07-1,42)$ & 1,09 & $(0,96-1-24)$ & 60,9 & 1,18 & $(1,05-1,32)$ & 1,05 & $(0,94-1,17)$ & 72,2 & 1,25 & $(1,08-1,43)$ & 1,07 & $(0,91-1,27)$ & 72,0 \\
\hline & $\begin{array}{l}\text { alapfokú } \\
\text { vagy alatta }\end{array}$ & 1,32 & $(1,13-1,54)$ & 1,19 & $(1,02-1,39)$ & 0,6 & 1,21 & $(1,11-1,31)$ & 1,03 & $(0,97-1,11)$ & 85,7 & 1,41 & $(1,27-1,58)$ & 1,20 & $(1,08-1,33)$ & 52,5 & 1,75 & $(1,43-2,14)$ & 1,40 & $(1,16-1,69)$ & 46,7 \\
\hline \multirow{3}{*}{ Magyarorszá } & felsőfokú & 1,00 & & 1,00 & & & 1,00 & & 1,00 & & & 1,00 & & 1,00 & & & 1,00 & & 1,00 & & \\
\hline & középfokú & 1,54 & $(1,27-1,85)$ & 1,45 & $(1,20-1,75)$ & 16,7 & 1,70 & $(1,46-1,97)$ & 1,52 & $(1,31-1,76)$ & 25,7 & 1,55 & $(1,33-1,81)$ & 1,36 & $(1,17-1,59)$ & 34,5 & 1,51 & $(1,34-1,70)$ & 1,33 & $(1,17-1,51)$ & 35,3 \\
\hline & \begin{tabular}{|l|} 
alapfokú \\
vagy alatta
\end{tabular} & 1,94 & $(1,61-2,33)$ & 1,75 & $(1,46-2,10)$ & 20,2 & 2,11 & $(1,84-2,42)$ & 1,79 & $(1,55-2,07)$ & 28,8 & 2,02 & $(1,70-2,39)$ & 1,65 & $(1,38-1,97)$ & 36,3 & 1,88 & $(1,6$ & 1,52 & $(1,31-1,76)$ & 40,9 \\
\hline
\end{tabular}

m1: 1. modell az életkorra, a válaszadóval való kapcsolatra, a válaszadó nemére korrigálva

m2: 2. modell az 1. modellben szereplő összes változó, az alkoholfogyasztásra és a dohányzásra korrigálva

AOR\%, a korrigált esélyhányados százalékos csökkenése a 2. modellben

OR: esélyhányados, Cl: konfidencia intervallum

Forrás: saját szerkesztés

2. táblázat: A nők halálozási esélyhányadosai a különböző iskolai végzettségü csoportok között, időszakonként és országonként

\begin{tabular}{|c|c|c|c|c|c|c|c|c|c|c|c|c|c|c|c|c|c|c|c|c|c|}
\hline \multirow{3}{*}{ Országok } & \multirow{3}{*}{\begin{tabular}{|c|} 
Iskolai \\
végzettség \\
szintje
\end{tabular}} & \multicolumn{4}{|c|}{ 1982-1989 } & & \multicolumn{4}{|c|}{$1990-1997$} & & \multicolumn{4}{|c|}{ 1998-2005 } & \multicolumn{5}{|c|}{$2006-2013$} & \\
\hline & & \multicolumn{2}{|r|}{$\mathrm{m} 1$} & \multicolumn{2}{|r|}{$\mathrm{m} 2$} & & \multicolumn{2}{|r|}{$\mathrm{m} 1$} & \multicolumn{2}{|r|}{$\mathrm{m} 2$} & & \multicolumn{2}{|r|}{$\mathrm{m} 1$} & \multicolumn{2}{|r|}{$\mathrm{m} 2$} & & \multicolumn{2}{|r|}{$\mathrm{m} 1$} & \multicolumn{2}{|r|}{$\mathrm{m} 2$} & \multirow[b]{2}{*}{ AOR\% } \\
\hline & & $\mathrm{OR}$ & $(95 \% \mathrm{Cl})$ & OR & $(95 \% \mathrm{Cl})$ & AOR\% & OR & $(95 \% \mathrm{Cl})$ & OR & $(95 \% \mathrm{Cl})$ & AOR\% & $\mathrm{OR}$ & $(95 \% \mathrm{Cl})$ & OR & $(95 \% \mathrm{Cl})$ & AOR\% & OR & $(95 \% \mathrm{Cl})$ & OR & $(95 \% \mathrm{Cl})$ & \\
\hline \multirow{3}{*}{ Oroszország } & felsőfokú & 1,00 & & 1,00 & & & 1,00 & & 1,00 & & & 1,00 & & 1,00 & & & 1,00 & & 1,00 & & \\
\hline & középfokú & 1,33 & $(0,98-1,81)$ & 1,33 & $(0,97-1,81)$ & 0,0 & 1,34 & $(1,14-1,57)$ & 1,32 & $(1,12-1,54)$ & 5,9 & 1,16 & $(0,93-1,45)$ & 1,15 & $(0,92-1,44)$ & 6,3 & 1,00 & $(0,79-1,28)$ & 0,94 & $(0,74-1,20)$ & n.a. \\
\hline & \begin{tabular}{|l|} 
alapfokú \\
vagy alatta
\end{tabular} & 1,23 & $(0,99-1,53)$ & 1,22 & $(0,98-1,53)$ & 4,3 & 1,34 & $(1,11-1,63)$ & 1,32 & $(1,09-1,60)$ & 5,9 & 1,44 & $(1,14-1,82)$ & 1,43 & $(1,14-1,80)$ & 2,3 & 1,93 & $\mid 1,39-2,68)$ & 1,80 & $(1,27-2,54)$ & 14,0 \\
\hline \multirow{3}{*}{ Fehéroroszoszág } & felsőfokú & 1,00 & & 1,00 & & & 1,00 & & 1,00 & & & 1,00 & & 1,00 & & & 1,00 & & 1,00 & & \\
\hline & középfokú & 1,14 & $(0,75-1,74)$ & 1,12 & $(0,73-1,70)$ & 14,3 & 1,47 & $(1,18-1,82)$ & 1,46 & $(1,18-1,81)$ & 2,1 & 1,19 & $(1,03-1,36)$ & 1,19 & $(1,04-1,36)$ & 0,0 & 1,42 & $(1,12-1,79)$ & 1,40 & $(1,10-1,79)$ & 4,5 \\
\hline & $\begin{array}{l}\text { alapfokú } \\
\text { vagy alatta }\end{array}$ & 1,20 & $(0,86-1,68$ & 1,21 & $(0,87-1,68)$ & n.a. & 1,32 & $(1,09-1,58)$ & 1,32 & $(1,09-1,58)$ & 0,0 & 1,33 & $(1,07-1,65)$ & 1,33 & $(1,07-1,65)$ & 0,0 & 2,22 & $(1,73-2,84)$ & 2,17 & $(1,66-2,82)$ & 4,1 \\
\hline \multirow{3}{*}{ Magyarország } & felsőfokú & 1,00 & & 1,00 & & & 1,00 & & 1,00 & & & 1,00 & & 1,00 & & & 1,00 & & 1,00 & & \\
\hline & középfokú & 1,03 & $(0,71-1,50)$ & 1,02 & $(0,70-1,49)$ & 33,3 & 1,08 & $(0,80-1,45)$ & 1,06 & $(0,78-1,44)$ & 25,0 & 1,18 & $(0,84-1-67)$ & 1,15 & $(0,82-1,63)$ & 16,7 & 1,19 & $(0,84-1,69)$ & 1,15 & $(0,82-1,63)$ & 21,1 \\
\hline & \begin{tabular}{|l|} 
alapfokú \\
vagy alatta
\end{tabular} & 1,38 & $(0,97-1,96)$ & 1,37 & $(0,96-1,95)$ & 2,3 & 1,17 & $(0,87-7,59)$ & 1,14 & $(0,87-1,59)$ & 17,6 & 1,67 & $(1,25-2,23)$ & 1,55 & $(1,16-2,08)$ & 17,9 & 1,81 & $(1,30-2,52)$ & 1,67 & $(1,21-2,30)$ & 17,3 \\
\hline
\end{tabular}

m1: 1. modell, az életkorra, a válaszadóval való kapcsolatra, a válaszadó nemére korrigálva

m2: 2. modell, az 1. modellben szereplő összes változó, az alkoholfogyasztásra és a dohányzásra korrigálva

AOR\%, a korrigált esélyhányados százalékos csökkenése a 2. modellben

OR: esélyhányados, Cl: konfidencia intervallum

Forrás: saját szerkesztés

Egészségfejlesztés, LXI. évfolyam, 2020. 2. szám 